\title{
Transmutation Theory in the Greek Alchemical Corpus
}

\author{
Olivier Dufault \\ Ludwig-Maximilians-Universität, München, Germany
}

This paper defines the nature and extent of transmutation theory in the Greek alchemical corpus as found in the texts attributed to Zosimus of Panopolis, "the philosopher Synesius," and "the philosopher Olympiodorus of Alexandria."1 By transmutation theory, I understand all explicit attempts made by Greek alchemical writers to explain how one substance can be entirely transformed into another. Greek alchemical texts, however, discussed "aurifiction" (gilding, colouring recipes) much more often than they did "aurifaction" (gold-making proper, transmutation). But even in the case when alchemical texts explicitly discussed an alchemical theory of transmutation, or at least of colouring, they are remarkably ambiguous so that any modern theoretical demarcation between aurifiction and aurifaction is practically impossible to

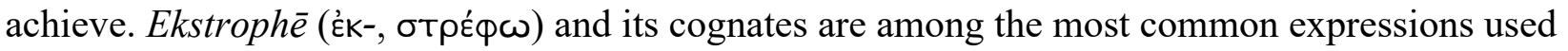
to describe processes of transformation, whether understood as superficial colouring or as complete transmutation. These words (strephō, ekstrephō, strophēe ekstrophē) literally mean a "turning" (strophē) or more specifically an "inversion" (ekstrophē), but they were also commonly used to mean a transformation. The problem is not simply that this term could refer to a surface transformation (colouring) as well as to a complete transformation (transmutation). Through the

1 While Synesius "the alchemist" was probably not the well-known Synesius of Cyrene (see Matteo Martelli, The Four Books of Pseudo-Democritus, in Sources of Alchemy and Chemistry 1, 2013], 48-56), it is harder to say if the attribution of the alchemical text attributed to Synesius was an attempt to ascribe the work to Synesius of Cyrene. On a possible identification of Olympiodorus the alchemist with Olympiodorus "the younger," the Alexandrian philosopher and commentator of Aristotle and Plato, see Cristina Viano, La matière des choses. Le livre IV des Météorologiques d'Aristote et son interpretation par Olympiodore (Paris: Vrin, 2006), 199-206. Both alchemical authors are difficult to date, but we know that the author of the alchemical Commentary attributed to Olympiodorus knew of the alchemical text attributed to Synesius, and it is consequently posterior. Moreover, Zosimus does not cite either of these authors, while they cite him. A tentative and relative chronology would thus puts Zosimus first, then "Synesius" and finally “Olympiodorus.” Zosimus's activity has been dated to the early fourth century by Michèle Mertens, Zosime de Panopolis, Mémoires authentiques. Les alchimistes grecs, vol. IV/1 (Paris: Les Belles Lettres, 1995), xii-xix, hereafter MA (works edited in this volume as Mémoire authentique I, Mémoire authentique II, etc. will be referenced here as MA 1, MA 2, etc.). 
idea of inversion, ekstrophe also appears to have meant something like the extraction (the "turning inside-out") of what was hidden in a substance. We could then more appropriately say that transmutation was not perceived as the transformation of a substance into something entirely new but as its reversion to what had always been there. As I will argue below, the commentary attributed to Olympiodorus described something similar to this reversion theory and it is the only transmutation theory that can be found in the texts studied here.

A closer look at the texts reveals that the apparent uniformity of ancient Greek alchemical doctrine implied in most modern discussions is not supported by the evidence. Theoretical explanations for the transmutation of metals into gold are relatively rare in the Greek alchemical corpus and are not found in the extant works of Zosimus of Panopolis, one of the most articulate ancient writers on alchemy. Texts from the Greek alchemical corpus provide very few systematic explanations of material metamorphoses but a lot of descriptions of technical procedures, the purpose of which is generally difficult to reconstruct. As Cristina Viano has pointed out, the operational context of ancient Greek alchemy must have influenced its description. ${ }^{2}$ As I will show below, while the descriptions of alchemical processes found in the treatise attributed to Synesius apparently borrowed from Greek philosophical vocabulary, it is also possible to trace their origin to ancient gilding or refining technologies.

This technical reading is not new. Although my reading of the text of Synesius could be compared to the approach of Arthur J. Hopkins, ${ }^{3}$ it is clear that this kind of methodology cannot be applied to all alchemical descriptions, and especially to all alchemical allegories. Allegorical writing does not always hide a message waiting to be translated. At the most basic level, allegory is the arbitrary statement of the similarity of the relations existing between two sets of interrelated terms. Allegory principally compares relations rather than the interrelated terms themselves: by saying that the relationship existing between the apparatus and mercury is similar to that existing between the earth and metallic ores, one does not primarily compare the apparatus to the earth (or mercury to metallic ores) but the relation that these terms have to each other. As such, the four terms themselves are not amenable to a direct translation. In other words, while code-names are sometimes deliberately used in alchemical texts, not all allegories should be read as an encoding

2 Cristina Viano, “Les alchimistes Gréco-alexandrins et le Timée de Platon," in Cristina Viano, ed., L'alchimie et ses racines philosophiques (Paris: Vrin, 2005), 91-92.

3 Arthur J. Hopkins, Alchemy, Child of Greek Philosophy (New York: Columbia University Press, 1934), 92-123. 
device. It is not entirely clear whether alchemical writers meant to describe transmutation when they described gilding and refining technologies, but when transmutation was explicitly "theorized," as we will see with Zosimus, the result was not an explanation of transmutation, i.e. the inclusion of a physical phenomenon in a larger theoretical framework able to explain other phenomena. Stoic cosmogony is a good example of such framework, since the notions of pneuma and tension (tonos) provided explanations not only for human life but also for many other questions about the natural world. On the other hand, the discussion of transmutation in Zosimus takes the form of allegorical writing providing a point of comparison - not an explanation of the type just described - between processes of refining, gilding and gold-making and analogical processes of purification through which one could reach back to Phōs, the name Zosimus gave to the primordial human, the "pneumatic" and "interior" human to which his eschatology pointed to. 4

After introducing the historiographic problem of Greek alchemical transmutation theory, the first part of this paper will assess the influence of Greek philosophical thought (mostly Aristotelian) on the alchemical corpus. The second part will assess the transmutation theories that can be found in two late alchemical commentaries: The Philosopher Synesius to Dioscorus: Notes on Democritus' Book, ${ }^{5}$ and On Zosimus' According to the Practice and what was said by Hermes and the Philosophers, the latter attributed to "the philosopher Olympiodorus of Alexandria." These two works offer particularly clear descriptions of alchemical processes, and, in the case of the Commentary attributed to Olympiodorus, refer abundantly to Greek philosophy. I will finally look at Zosimus' Lessons on Excellence, his only work alluding to transmutation, and attempt to explain what he meant by these allusions.

\section{Modern hypotheses on the ancient theory of transmutation}

The notion that Greek alchemy can be traced to Greek physics is as old as Greek alchemy itself. This traditional understanding has traced alchemy and alchemical theory (which it has closely

4 See MA 1.

5 Matteo Martelli, The Four Books of Pseudo-Democritus, 122-149, hereafter Syn. Alch.

6 Marcellin Berthelot and Charles-Émile Ruelle, Collection des anciens alchimistes grecs, 3 vols. (Paris: Georges Steinheil, 1887-8), 69-104, hereafter CAAG. 
united) to the Presocratic notion of the unity of being seen in the phrase "the universe is one" (hen to pan), which was also current in ancient philosophy. In the historiography of the last two hundred years, the first stage of the alchemical work is usually described as the "blackening" (melanōsis), in which alchemists recreated the universe's primary constituent. Alchemical authors, it is often noted, derived this notion from Aristotle's "prime matter" (prōtē hulē) or from some Presocratic idea of a primary element. After this general agreement, however, modern theories on ancient transmutation diverge.

With few exceptions, historians who touched on ancient Greek alchemy have argued that the Greek alchemical corpus presented a single transmutation theory. ${ }^{7}$ The different theories proposed by modern scholars can be classified into three major groups:

\section{1) The Natural Sympathy Theory}

The "natural sympathy theory" was described by André-Jean Festugière, who focused on allusions to the relation, or "kinship" (suggeneia) between natural substances, and most notably in the pseudo-Democritean Physica et Mystica (Natural and Secret Questions). ${ }^{8}$ According to this theory, transmutation was principally conceived as the mixture of reactive ingredients, with or without reference to prime matter. André-Jean Festugière and others believed that Bolos of Mendes had written a fundamental work of Greek, Latin and Arabic alchemy, the pseudoDemocritean Physica et Mystica.${ }^{9}$ Festugière thought that Bolos was the first to have explained transmutation using the notion of natural sympathy and to have authored the famous axiom of

\footnotetext{
${ }^{7}$ Three exceptions are: Frank Sherwood Taylor, The Alchemists, Founders of Modern Chemistry (New York: Schuman, 1949), 2, whose synthesis of transmutation theories was judiciously vague; Lawrence M. Principe, The Secrets of Alchemy (Chicago: University of Chicago Press, 2012), 16, 24, who surveyed Zosimus' and Olympiodorus' ideas and who did not point out any shared ancient Greek transmutation theory between these two authors; and Cristina Viano, whose works on Greek transmutation theory will be examined below. 8 André-Jean Festugière, La révélation d'Hermès trismégiste (Paris: Belles Lettres, 1944), 235; Jack Lindsay, The Origins of Alchemy in Greco-Roman Egypt (London: Muller, 1970), 116-117.

9 The theory was first proposed by Max Wellmann, Die quбıkó des Bolos Demokritos und der Magier Anaxilaos aus Larissa, Teil 1, Akademie der Wissenschaften, 1928 (Abhandlungen der Preussischen Akademie der Wissenschaften. Phil.-hist Klasse; 7), 3-80. It has been rebutted by several scholars since then. See Martelli, The Four Books of Pseudo-Democritus, 36-44.
} 
Greek alchemy, "the nature is charmed by the nature, the nature masters the nature, the natures conquers the nature." 10 According to Festugière's historical reconstitution of alchemy, Bolos was the inventor of alchemy, and alchemy was consequently inseparable from Greek philosophy. Festugière could hardly ignore the process of blackening, given how often it is mentioned in the Greek alchemical corpus, but this process does not fit well with the theoretical model he suggested. The theory of alchemical transmutation, he argued, consisted in obtaining the unqualified substrate through blackening, which he understood as the fusion of metal into a (usually) dark mass, and in mixing this substrate with substances chosen for their reactivity according to the principle of sympathy. ${ }^{11}$ Such principles, as seen for example in Pliny or Nepualius' On Antipathy and Sympathy do not involve the creation of a "receptive" or "unqualified substance" and concerned specific substances. ${ }^{12}$

To support his claims, Festugière gave some examples taken from recipes attributed to pseudo-Democritus where the effects of products were interpreted as sympathetic interactions. Here is the most explicit instance:

Take white sulphur, whiten it by grinding it in the sun with urine, or alum and salt brine; it will shine completely white. Grind it with realgar or with the urine of a heifer for six days, until it becomes a drug similar to marble. And if it does, it is a great mystery: for it whitens copper, softens iron, takes away the cry of tin, takes away the fluidity of lead, makes substances unbreakable and makes dyes stable. For sulphur, when mixed with sulphur, makes substances divine, since [sulphurs] have great affinity with each other. The natures delight in natures. ${ }^{13}$

10 For the purported origin of the axiom, see the Physica et Mystica $\S 3$ in Martelli, The Four Books of PseudoDemocritus, 82-85 (=CAAG 2.42.21-43.22) and Syn. Alch. 33 (=CAAG 2.56).

11 Festugière, La révélation, 234-235. Festugière's only follower was Jack Lindsay, who also combined the theory of sympathetic transmutation with that of the ontological scale of metals and provided an original reading of the tripartite axiom of the Physica et Mystica explaining this theory. As far as I know, no sources can be mustered to back Lindsay's claims.

12 See, e.g. Pliny, Natural History, 28.23.6 and Nepualius, On Antipahty and Sympathy, transcribed by W. Gemoll,

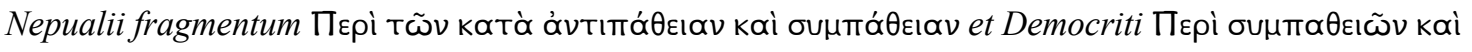
óvтıт $\propto \theta \varepsilon ı \tilde{\omega} \nu$ (Striegau: Städtisches Realprogymnasium, 1884).

13 Translation from On the Making of Silver $§ 4$ in Martelli, The Four Books of Pseudo-Democritus, p.108-109. The

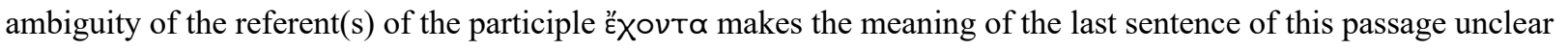

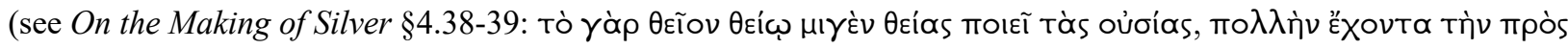


As seen in this example, pseudo-Democritus used vocabulary related to the theory of natural sympathy, but did not provide an explicit discussion of the relationship between this explanatory model and transmutation. Festugière proved unable to cite any evidence showing that blackening was a necessary or common part of the recipes. In no place does pseudo-Democritus imply the concept of an unqualified substrate (molten lead or metal according to Festugière). In fact, the recipes attributed to him suggest that a single ingredient was thought to have different effects depending on the metal it was mixed with. ${ }^{14}$ This rules out the possibility that the molten metal in which the products were thrown was perceived as prime matter or as an unqualified substrate. On the contrary, the author's concern with the different results produced by the mixing of a single substance to different metals implies that the molten metals were considered to have different qualities.

The notion of sympathy is present in what is left of the Four Books of pseudoDemocritus, the treatises known as the Physica et Mystica and On the Making of Silver, but it is not integrated into the alchemical theory Festugière had in mind. In fact, blackening itself - the operation supposed to produce the unqualified substrate - is absent from the extent summaries of the Four Books, as are references to an unqualified substrate. Considering that Bolos was thought by Festugière to be the real author of the Four Books of pseudo-Democritus and to have first introduced Greek philosophy into a purely technical pursuit, that of dyeing minerals and clothes, it is surprising that the recipes attributed to pseudo-Democritus contain so few Greek philosophical concepts. It rather appears as if the vocabulary of natural sympathy was a descriptive tool for the author(s) of the extant Physica et Mystica and On the Making of Silver and that it was not the expression of a deliberate interrelation between a body of theoretical doctrines and a set of practices.

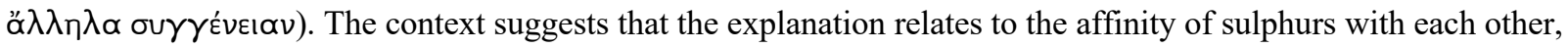
and thus that transformation is described here as a "divinization” of substances. Following Festugière's translation

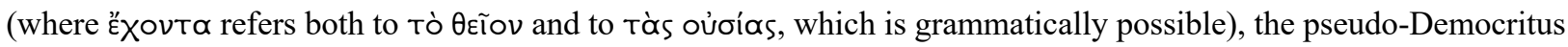
would have considered transmutation as the sympathetic reaction of sulphurs with metals (see also PseudoDemocrito, Scritti alchemici. Con il commentario di Sinesio. Edizione critica del testo greco, traduzione e commento di Matteo Martelli (Paris: S.É.H.A / Milan: Archè, 2011), 210, n.20.

14 Festugière, La révélation, 236-237. 


\section{2) The Maturation Theory}

The maturation theory is based on three ideas: 1) the long-standing notion that metals grew inside the earth found in Greek and Latin literature; 2) Aristotle's theory of the generation of metals, according to which metals and non-fusible minerals are produced respectively by humid and by dry exhalations inside the earth; and 3) the notion that all types of metals were reduced to one, gold, and that their differences was explained by their different stages of "maturation." Alchemy, then, would have consisted of finding the correct technique to speed up the natural "gestation" process of metals by which they would have naturally transformed into gold.

Mircea Eliade showed that many traditions around the world supported the first notion, and Robert Halleux conclusively showed that it was also widespread among Greek and Latin writers. ${ }^{15}$ Strabo, Pliny and the Christian Origen were sceptical of stories about "fallowing" mines, but the neoplatonist Plotinus took the growth of stones in the earth as a matter of fact. ${ }^{16}$ If this notion was well received by Plotinus, it is plausible that other Hellenized scholars shared it as well, and thus that the idea had some credit among writers of alchemical texts. Metaphors that evoked the natural maturation of metals inside the earth were also used to describe alchemical processes. Zosimus compared dyeing processes inside the alembic to the "cooking" of the embryo in the womb ${ }^{17}$ and the alchemical treatment of metals to the healing of bodies. ${ }^{18}$ Writing perhaps three centuries later, Stephanus compared the alembic to the universe, alluding to Aristotle's exhalation theory:

Just as all these [transformations of elements into other elements] come from the exhalations (anathumiaseonn) that come from the sky, which is laid arching over the earth, so the intense transformations occur from the chutra or the lopas [i.e. the bottom part of

15 Mircea Eliade, Forgerons et alchimistes (Paris: Flammarion, 1977), 35-44. For similar theories, see John Hudson, The History of Chemistry (New York: Chapman \& Hall, 1992), 17. See also Hugh W. Salzberg, From Caveman to Chemist (Washington, DC: American Chemical Society, 1991), 44; Trevor H. Levere, Transforming Matter

(Baltimore: John Hopkins University Press, 2001), 5. On mineral sexuality see Robert Halleux, "Fécondité des mines et sexualité des pierres dans l'antiquité gréco-romaine," Revue belge de philologie et d'histoire 48 (1970): 16-25.

16 Strabo, 5.2.6; Pliny, 34.165; Origen, De Principiis, 3.1.2; Plotinus 4.4.27.

17 CAAG 216.4-9.

18 MA 1.18, MA 10, MA 11, CAAG 170. 
an alembic $]^{19}$ as from the earth, and from the phanos $^{20}$ laying over it as from the sky. ${ }^{21}$

Even if the use of this allegory implies the belief that metals undergo slow qualitative changes in the earth and change species as they grow (just as metals are transformed into gold in the alembic), it is not necessary to deduce from this allegory that metals naturally turn into gold as if they all followed the same hierarchy of metallic substances. This reading would be valid only if we agreed that analogies do not only indicate relationships between pairs of terms but also imply a similarity between the paired terms themselves. Saying that the alchemical apparatus functions like the earth does not necessarily imply that all metals can and will be eventually transformed into gold but simply that their transmuting powers are similar. In fact, the notion that each metal occupies a rung on a single ladder of metallic substances is not an idea found in the Greek alchemical corpus.

Moreover, the notion that metals naturally mature to become gold did not originate in Aristotle, nor can it be found in ancient Greek or Latin sources. In the Meteorologica, Aristotle wrote that the heat of dry exhalations inside the earth produced coloured ashes or rocks and that humid exhalations transformed into metals by condensing and hardening, but he did not state that differences in species of metals were due to the time spent by exhalations condensing or burning inside the earth. ${ }^{22}$ Rather, he explained specific differences between metals and between homeomeres in general (i.e. substances that he perceived as being composed of the "same part," such as bone, blood, or flesh) by referring to their "passive qualities" (pathêtika), by which he meant the specific way in which substances react to external forces, e.g. the fact that some melt rather than harden when heated or that some bend rather than break when twisted. In turn, he explained differences in qualities by referring to the fact that metals are made up of different ratios of elements. While Aristotle was not preoccupied by the nature of these ratios, he thought that the underlying species of homeomeres was directly observable in their different passive

19 See MA, cxxi.

20 The phanos is here the equivalent of the phiale, a libation vessel, which in alchemical treatises meant the top part of the apparatus. In the works attributed to Zosimus, the phanos can also mean an entire apparatus which served the purpose of "fixing mercury and to make it yellow through exhalations of sulphur" (MA 2.6-10). See MA, cliii-clxi. 21 Stephanus of Alexandria, Lessons and Letter to Theodorus, in Julius L. Ideler, Physici et medici graeci minores, vol.2 (Berlin: Reimer, 1841), 9.245.3-7, hereafter Ideler.

22 Aristotle, Meteorologica 3.6.378a15-378b6. 
qualities. ${ }^{23}$ It is improbable that readers of the Meteorologica and the treatise On Generation and Corruption would have concluded that Aristotle thought of the different species of metals as the different maturation stages of gold. This is not surprising, since his understanding of specific difference was entirely dependent on sense perception and, consequently, on the visible differences between the passive qualities of metals.

To claim that ancient Greek alchemists believed that all metals are forms of gold in a more or less developed state would require us to show how alchemical writers coaxed this theory from Aristotle or from some other system of belief. Eliade did not pursue the question in much detail, and Halleux only demonstrated the pervasiveness of the belief in the reproductive capacities of minerals, not in the belief that all metals were all slowly maturing to become gold. As far as I can tell, the maturation theory as I have formulated it is not found in Greek alchemical texts.

\section{3) The Form-Transfer Theory}

Inspired by Karl von Prantl's 1856 Die Keime der Alchemie bei den Alten, Edmund O. von Lippmann formulated the most extensive version of the form-transfer theory of transmutation in his influential Entstehung und Ausbreitung der Alchemie. ${ }^{24}$ His hypothesis involved two steps. Ancient alchemists produced blackening first, which consisted of the extraction of all qualities from a metallic body so as to transform it into a purely "unqualified substrate" or "receptive body," a material vessel for the form of gold. This "unqualified substrate" of everything has been discussed since antiquity under the name of prime matter or materia prima, following Aristotle's use of the term prôte hulē to describe the "nature" (phusis) of things, which he also called "the first things." 25 In a critical statement about this "nature," Aristotle wrote, "although there is a matter (mian hulēn) of the perceptible bodies (a matter out of which the so-called 'elements' come-to-be), it has no separate existence, but is always bound up with a contrariety

\section{Ibid. 4.8-12.}

24 Edmund O. von Lippmann, Entstehung und Ausbreitung der Alchemie (Berlin: Springer, 1919), 324. For similar theories, see Hopkins, Alchemy, 123; Holmyard, Alchemy, 26; Robert J. Forbes, Studies in Ancient Technology, vol.1 (Leiden: Brill, 1955), 133.

25 See, among other passages, Aristotle, Metaphysics, 5.4, and On Generation and Corruption, 2.1. 
(enantiōsis). ${ }^{26}$ Aristotle refers to the so-called elements (stoicheia) of the Presocratics (fire, air, earth and water) as secondary "elements," which are constituted by what he properly called elements as well as active and passive "principles," the dry, the humid, the hot and the cold. These principles, the elements proper, constitute the so-called elements, which he called the "simple bodies," by being opposed in relations he called "contrarieties" (e.g. fire is dry and hot). ${ }^{27}$ Considering this definition, it is unlikely that Aristotle thought that prime matter could exist and be perceptible as an entirely "unqualified" thing. ${ }^{28}$ Whether modern historians considered that alchemical writers misunderstood Aristotle on that point or not, it is often stated in histories of Greek alchemy that the product of blackening was considered to be this prime matter: something that had no form, no specific qualities - an "unqualified substrate" - and which, just because it was radically unqualified, could become anything if one were to incorporate qualities into it.

According to the form-transfer theory, the second step of the transmutation process involved mixing a metallic body — the "unqualified substrate" or "receptive body" — with "vapours" (aithalai), "pneuma," "soul," or "materials" (hulai; see discussion below) — which Lippmann also called logoi spermatikoi ("seminal blueprints/recipes"), the "philosophers' stone," the "world egg," or the "seed of gold." According to Lippmann, alchemists tried to produce an alchemical gold that worked as a "seed" on prime matter by transforming its inchoate mass into real gold. ${ }^{29}$ Without providing much evidence from the alchemical corpus, Lippmann argued that this theory was based on the syncretism of many Greek philosophical traditions. Also assuming that Greek alchemical writers were influenced by Greek philosophy and that they worked on the assumption of a theory of transmutation, Holmyard quoted an unknown text to that effect:

The underlying idea seems to have been that since the prime matter was the same in all substances, an approximation to this prime matter should be the first quest of alchemy;

26 Aristotle, On Generation and Corruption, 2.1 (trans. Joachim).

27 See Aristotle, On Generation and Corruption, 2.1-3 and Meteorologica 4.1.

28 See Marwan Rashed in Aristotle, De la génération et de la corruption (Paris: Les Belles Lettres, 2005), xcii-ciii. The debate whether Aristotle subscribed to the traditional concept of prime matter is still ongoing but is not relevant to my current purpose. For a recent example, and defence of the "traditional" theory of prime matter, see Frank A. Lewis, "What's the Matter with Prime Matter," in Oxford Studies in Ancient Philosophy 34 (2008): 123-146.

29 Lippmann, Entstehung, 324. 
when such a substance had been obtained it was to be successively impressed with 'pure qualities which one after another should gradually rise in the scale of metallic virtue' to the perfection of gold. ${ }^{30}$

The form-transfer theory here appears to have been mixed with the notion of the hierarchy of metals through an unreferenced quotation. Hopkins argued that a "fundamental theory of alchemy" could be found in a text from Zosimus, providing the following translation of a passage from the Collection des anciens alchimistes grecs of Berthelot and Ruelle:

But our gold which possesses the desired quality can make gold and tint [transmute] into gold. Here is the great mystery - that the quality becomes gold and it then makes gold. ${ }^{31}$

The source of the quotation, entitled On Excellence and Interpretation by the Divine Zosimus cannot be attributed to Zosimus as it was by Berthelot and Ruelle since it includes a reference to Stephanus of Alexandria. Hopkins also appears to have made no clear difference between dyeing and transmutation in another text, which he cited as "the fundamental thesis of alchemistic philosophy":

All sublimed vapor is a spirit and such are the tinctorial qualities ... The vapor is a Spirit — the spirit which penetrates into the Bodies [of the metals] ... Above, the things celestial and below the things terrestrial ... Such is the useful thing: the tinctorial element. [This is to be understood as the kinetic coloring principle, not the color but the ability to impart color, in analogy to the dye] ... The spirit ... has not been destroyed but it has penetrated into the depths of the metal when the operator has accomplished his work ... And when the preparation is colored then it, itself, colors in its turn. ${ }^{32}$

Pneuma ("spirit"), in this text from the Summaries to Eusebeia or perhaps Theosebeia (otherwise known as a dedicatee of many if not most of the works attributed to Zosimus), ${ }^{33}$ is identified with

30 Holmyard, Alchemy, 26.

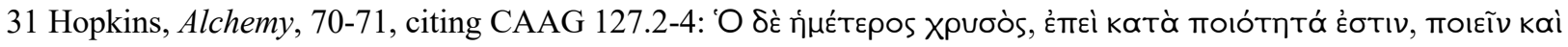

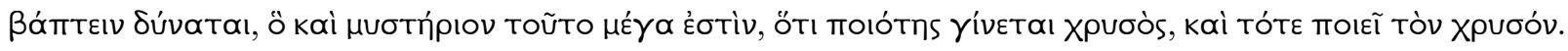

32 Hopkins, Alchemy, 74, citing CAAG 150.12sq.

33 See CAAG 204.9 where in a specific treatises of the Summaries to Eusebeia, M has hōs theosebeian, which

Ruelle corrected for $\bar{o}$ Theosebeia (i.e. an address to Theosebeia). This, incidentally, would show that the text is not a 
sublimed substances (aithalai) with "dyeing qualities" (poiotētes hai baptikai). Hopkins understood these qualities in the Aristotelian sense of the "entelechy" of gold (rather than as dyeing agents), but the notion of transmutation is not explicit in the passages he cited and the philosophical influence implied in this expression cannot be found in the texts that we can attribute to Zosimus. ${ }^{34}$ None of these modern authors appears to have thought it necessary to explain how alchemical writers, whom they presented as deeply influenced by Aristotle, thought that "qualities" could be instantiated without a material substrate, or how they actually considered that matter could be radically unqualified.

As far as I know, Cristina Viano is the first - and only — scholar to have directly questioned the validity of this model by confronting Greek physical theories directly with evidence taken from the alchemical corpus. Viano identified Plato and Aristotle as the two main influences on alchemical writings and concluded that the alchemical commentators did not meet the requirements of their philosophical masters. ${ }^{35}$ Besides showing that alchemical texts borrowed much of the Greek physical language used by Aristotle and Plato (such as that of potentiality and act), ${ }^{36}$ Viano described three different transmutation theories, similar to the three families of theories presented here: 1) a form-transfer theory, which she detected in Synesius and Olympiodorus" "hypostatic body" (on this, see below); ${ }^{37}$ 2) a "maturation theory" claiming that all metals are in fact gold; ${ }^{38} 3$ ) a more speculative reconstruction based on the Aristotelian theory of mixing, and similar in that regard to what I have called the "natural sympathy" theory. According to Viano, this last theory could have answered a criticism that Proclus levelled against "those who claim to produce gold" in his Commentary on the Republic, namely that these men erred in believing that they could produce things through mixing when nature produced them

re-written summary but an extract.

34 Hopkins, Alchemy, 123.

35 See Viano, “Les alchimistes Gréco-alexandrins,” and Viano, “Aristote et l'alchimie grecque.”

36 MA 2.16, Stephanus, 3.209.20 Ideler, CAAG 71.18, 93.18. Other uses of dunamis and energeia in their Aristotelian sense can be found in the Summaries to Eusebeia (CAAG 114.11, 172.22, 173.25, 192.10-18, 193.15, 205.1-15).

37 Viano, “Aristote et l'alchimie grecque," 199-200.

38 Viano, “Aristote et l'alchimie grecque,” 201-202, based on Stephanus, 7.233.36 Ideler. 
without mixing. ${ }^{39}$ Basing her argument on passages from Stephanus of Alexandria, Viano argued that artisans who had analysed the composition of gold, separated its ingredients, and studied its genesis could have tried to reproduce the natural conditions for its creation, thus avoiding Proclus' accusations as well as "the [Aristotelian] dogma of the eternity of substance and species." ${ }^{40}$

As Viano made clear, Aristotelian vocabulary occupies an important place in the Greek alchemical corpus. We run into problems, however, when we start analysing this corpus as if it were the product of a single and coherent philosophical school. If one simply needs to "mature" or "perfect" metals so that they reach their true nature (i.e. gold), what would be the use of "blackening" if this operation was meant to remove all qualities from a substrate? Even if we ignore the fact that prime matter was probably a purely theoretical concept, it would be superfluous if transmutation was understood as a form of mixing. The main cause of transformation in Aristotelian mixing was the idea that substances autonomously tend to "dominate" (kratein) each other, a very common notion in Greek philosophy that is also present in the pseudo-Democritean axiom, "a nature is charmed by a nature, a nature dominates a nature, a nature wins over a nature." ${ }^{41}$ Descriptions of mixing in the Meteorologica and On Generation and Corruption, however, show that mixing only required the contact of two reciprocating and equally "dominating" substances. ${ }^{42}$ To work as transmutation theories, Aristotelian mixing and

39 Wilhelm Kroll, Procli Diadochi in Platonis Rem publicam commentarii (Leipzig: Teubner, 1899-1901), 2.234.1415. Proclus wrote that those who claimed to produce gold by mixing certain species of metal are just like astrologers who believe the world works on the same rational principles that they use to make prognostic tables. Just as the cause of events in the universe is prior to the movement of the stars, Proclus reasoned, "nature creates the single species of gold before the mixing of the species they [i.e. those who pretend to produce gold] speak of."

40 Viano, “Aristote et l'alchimie grecque," 206-210.

41 See Empedocles, fragments B17.38, B26.3, Anaxagoras frag. A42.30, A48, A100, B12, Diogenes of Apollonia frag. B5 and Archelaos frag. A1.10-13 in H. Diels and W. Kranz, Die Fragmente der Vorsokratiker (Hildesheim: Weidmann, 1951), hereafter DK. See also Plato Timaeus 39a-40b, 56e, 57a-b. The generation of the embryo, which is compared to a dye in the Summaries to Theodorus (CAAG 216.4-9), could also be described as a process of domination. See, e.g., Hipponax frag. A14 DK, Aristotle (Generation of Animals, 4.3.767b6-768a-10), Hippocratic Corpus (On Flesh, 3, 4.7, 8.2; On Sperm and the Nature of the Child, 6).

42 See Aristotle, On Generation and Corruption 1.10, with Dorothea Frede, "On Generation and Corruption 1.10. On Mixture and Mixables," in F. de Haas and J. Mansfeld, eds., Aristotle's On Generation and Corruption I 
Stoic fusion, which works according to similar principles, do not require blackening. They do not ask for a substance to be reduced to prime matter for it to be able to mix and produce new substance. The same could be said of the natural sympathy theory. Why would it have been thought necessary to remove all of a given body's qualities before allowing it to interact with other bodies? How would an "Aristotelian" prime matter, devoid of passive qualities - and thus of potential for interaction - react with other bodies in a "Stoic," sympathetic universe?

In other words, in what kind of ancient intellectual environment could these multiple theories have coexisted? It seems to make little sense to continue assuming that alchemical writers operated on philosophical grounds, especially if the result is to conclude that they were bad philosophers. Greek philosophy is not the single interpretive key of the Greek alchemical corpus; rather, philosophy was only one of the systems of reference within which alchemical writers described dyeing and metallurgical practices.

Before analysing the corpus to identify its transmutation theories, let me point out two principles guiding my thinking. First, building on the preceding review of the historiography on ancient transmutation theory, I will refrain from inferring a single transmutation theory from the few theoretical passages found in the Greek alchemical corpus. Like any tradition, Greek alchemy was not monolithic, and it evolved over time. Secondly, I will refrain from assuming that alchemical authors based their work on Greek philosophical theories until proven otherwise. Zosimus, for example, approved of "demonstrative reasoning" (logos apodeiktikos) and went so far as to write the treatise "On the Letter Omega" (MA 1) to justify his interest in technical demonstrations, such as the importance of using the right equipment ${ }^{43}$ and correct procedure. ${ }^{44}$ It would be consequently just as valid to hypothesise that Zosimus was concerned with achieving the right technique and that his descriptions were informed by "technically transmitted" (technoparadotos) $)^{45}$ information, not by Greek philosophical theories.

\section{Aristotelian influence on transmutation theory}

(Oxford: Oxford University Press, 2004), 289-314.

43 MA 1.11-19, 171-189; MA 7.1-14; MA 8.1-30.

44 MA 10.93-95.

45 MA 3.2. 


\section{Alchemical Axioms}

By their nature, alchemical axioms offer a privileged but fairly narrow perspective on the theoretical ideas that could lie behind Greek alchemy. These axioms were frequently repeated throughout the corpus and we can consequently assume that they may point to some constant characteristics of the Greek alchemical tradition. Alchemical axioms, however, are vague and short and they do not yield easily to unambiguous interpretations. It is consequently difficult to find in them the lasting influence of a specific philosophical school. The notion that "the universe is one," for instance, was attributed to Chymes, who was also described as a student of Parmenides. ${ }^{46}$ It recalls the doctrine of Presocratic monists, but by late antiquity this notion was shared by Neoplatonists and had also been common for many centuries among Stoics.

Another alchemical axiom, according to which "a nature charms a nature, a nature vanquishes a nature, a nature dominates a nature," is not just related to the theory of natural sympathy, but also follows an archaic Greek idiom describing physical transformations. As noted above, the Greek verb "to dominate" (kratein) was used very early in Greek literature to describe physical transformation. Even though Aristotle used the metaphor of domination in his explanations of increase, mixing, and absolute generation and destruction ${ }^{47}$ it would be difficult to find in this metaphorical short-cut anything other than a way to describe physical change. A less well-known axiom attributed to "the peasant Acharantos" (or "Achaab") states that "wheat generates wheat, human sows human and gold breeds gold." This is remarkably similar to a Greek saying according to which "a human generates a human,"48 and which appears for the first time in Aristotle's Metaphysics. ${ }^{49}$ This axiom is not a sign that alchemical writers were working within the framework of Aristotelian philosophy since this idea did not remain within the bounds of the Peripatetic tradition. ${ }^{50}$

46 The name of Chymes is alternatively spelled Chimēs, Chêmès and Chumēs (CAAG 84.12, 169.9, 172.17,182.18, 183.22). Similarly, the name for alchemy is spelled chimeia, chèmeia and chumeia (CAAG 94.17, 209.5, 213.15). 47 See his On Generation and Corruption, 1.5 (increase), 1.10, 2.7 (mixing) and Meteorologica 4.1 (generation and corruption).

48 CAAG 30.9-19 and 24-26, 89.8-11, 160.14-15, 258.10.

49 Metaphysics, 1032a25, $1033 \mathrm{~b} 32$.

50 See Philo, Quod deus sit immutabilis, 117.3-118.1 and Athenagoras, De resurrectione, 23.3. 


\section{Citations of Aristotle}

Of the nine citations of Aristotle found in the corpus, three are in treatises that Berthelot and Ruelle attributed to Zosimus. Each of these is found in a different treatise, and of these three treatises, two were misattributed to Zosimus by Berthelot and Ruelle. ${ }^{51}$ The only citation of Aristotle attributed to Zosimus comes from the Summaries to Eusebeia (kephalaia pros Eusebeian). This collection, unlike the collection known as the Authentic Memoirs or Books (gnēsia upomnèmata), is more likely to include summaries rather than extracts or complete texts, as explicitly stated by the title found at the beginning of the Summaries to Eusebeia in manuscript M. ${ }^{52}$ The only other collective name given to a series of texts attributed to Zosimus is the Summaries to Theodorus (pros Theodoron kephalais), and in this case it is much clearer that they consist of summaries rather than extracts. If the Summaries to Eusebeia were indeed a collection of summaries rather than extracts, the fact that they mention Stephanus of Alexandria (c. $600 \mathrm{CE})$ twice ${ }^{53}$ suggests that the same flexible editorial standards could have been used for all the summaries, and that these should be considered as summaries proper rather than copies from works by Zosimus. Be that as it may, I will consider the Summaries to Eusebeia in the following as a group of summaries written after Stephanus, and which should not be considered to represent the work of Zosimus as far as the vocabulary is concerned. Incidentally, considering this compilation of summaries as a later work also reinforces the impression that references to Aristotle in the Greek alchemical corpus were made more toward the end of the corpus' life, around $1000 \mathrm{CE}$, than at its beginning. If this hypothesis were to be substantiated in the future, we might also expect to find that the quotation from Aristotle in the Summaries to Eusebeia was a later gloss.

Aristotelian vocabulary and concepts

This hypothesis can be provisionally substantiated by examining the use of dunamis (power,

51 CAAG 128.20 and 206.2. See MA, cvi-cix and 263-267.

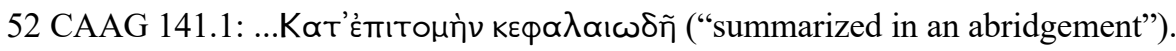

53 CAAG 162.19-20 and 173.1. 
potentiality) and energeia (activity, force, actuality) in the works of Zosimus. As in the medical and dyeing tradition, dunamis and energeia were sometimes used interchangeably by alchemical writers to refer to a drug's potency. ${ }^{54}$ Energeia was also used in alchemical and related texts to mean a process or an operation. ${ }^{55}$ But, as Viano noted, authors of alchemical works also used energeia and dunamis according to their specific metaphysical sense as found in Aristotle and in the texts of many later Greek philosophical schools. Zosimus, however, usually followed the medical and technical tradition seen in the work of Dioscorides and in the Leiden and Stockholm alchemical papyri in using the word dunamis to mean the power or efficacy of a drug. ${ }^{56}$ Of the mentions of energeia that can be attributed to Zosimus, one shows that he used the term to refer to a process or an operation ${ }^{57}$ and two refer to the action of substances. ${ }^{58}$ Of the three treatises in which Zosimus used either energeia or dunamis with the technical and rigorously exclusive meanings intended by Aristotle, only one can be securely attributed to Zosimus. ${ }^{59}$ Here is the passage in question:

54 Dioscorides, De Materia Medica, Pr. 1.2; See P.Leid. 1.147 in Robert Halleux, Les alchimistes grecs, Tome 1: Papyrus de Leyde, Papyrus de Stockholm, Fragments de recettes (Paris: Belles Lettres, 1981), 90.

55 E.g. Stephanus, 3.209.20 Ideler; CAAG 93.18; A. Henrichs and K. Preisendanz, Papyri Graecae magicae. Die griechischen Zauberpapyri, 2 vols. (Leipzig: Teubner, 1973-1974), 4.274 (hereafter PGM). The codicological and lexical relationships between the Leiden and Stockholm alchemical papyri and some codices edited in the Greek Magical Papyri was already recognized by Karl Preisendanz in 1928 (see the introduction to the PGM and PGM, vol. 2, 86 where he notes the similar hand-writing of PGM/PDM XII, PGM XIII and P. Leid. i 397 X, the last of which was said to share the same handwriting as P. Holm. by Halleux; see his Les alchimistes grecs, Tome 1, 9-13). The link between the two set of documents has only recently become the focus of several interesting studies. For a more detailed discussion, see William Brashear, "The Greek Magical Papyri: an Introduction and Survey," in ANRW 2.18.5 (1995), 3380-3684 and Michela Zago, Tebe magica e alchemica. L'idea di biblioteca nell'Egitto romano: la Collezione Anastasi (Padua: Libreria Universitaria, 2010), 31-93.

56 CAAG 159.5, 171.1, 171.4, 177.10, MA 4.65, 4.91, MA 5.10, MA 14.

57 CAAG 190.9.

58 CAAG 193.16 and 218.12.

59 The references are found in CAAG 172.22, 173.22 (from a treatise of the Summaries to Eusebeia including a quotation of Stephanus) and CAAG 192.10-12, 18, 193.15 (from the last treatise of the Summaries to Eusebeia). The only citation directly attributable to Zosimus is at MA 2.16. Even there, this treatise suffered heavy editorial interventions in the course of its transmission (see the introductory note to MA 2 at p.120-121) and it is possible that extraneous material was added to the text. 
And you will be surprised by this text as it obviously hides two hidden doctrines [musteria]: that we do not seek why the vapour of sulphur, which is white and which make everything white shows mercury to be yellow. And this happens even if it is not burnt. Moreover, being white in potentiality and in actuality [dunamei kai energeiai] and being burnt and solidified by something white, why is it yellow (when) it is deposited? Accordingly, the new generation [of 'alchemists'] should definitely research this before anything else. The second hidden doctrine, I think, is that it is not solidified alone but with the entire compound. ${ }^{60}$

Potentiality and actuality here have a specific Aristotelian sense since mercury, being "white" (the colour alchemical writers used to describe silver) and capable of whitening gold when amalgamated with it, can be said to be white in actuality and in potentiality. Mercury is extracted from a mineral called cinnabar (kinnabari), a compound of mercury and sulphur. Appropriately mixed together, these elements can be recombined to form cinnabar, which is bright red or reddish-brown in hue. This spectrum of colours is not too far from that covered by the Greek word xanthos ("yellow"), and for this reason mercury can be said to be potentially white and yellow at the same time. This single use of the words according to their Aristotelian meaning is exceptional in the works attributed to Zosimus. The fact that Zosimus did not usually employ these terms with their Aristotelian meaning while the latter use was reaffirmed over time could also explain why the alchemical commentary attributed to Olympiodorus glosses his use of the term energeia as an "operation." The commentary starts with a line from Zosimus' text enjoining readers to execute "the operation (energeia) of maceration." Paraphrasing this passage, the commentary states that Zosimus "urged for the efficacious practice" (tèn emprakton ergasian). "Indeed," he added, "here energeia must be understood as an operation (praxis)." ${ }^{61}$ Most probably, the commentator was aware of misunderstandings over this word, and considering that instances of energeia used in their Aristotelian sense are not as common in texts attributed to Zosimus as in other alchemical texts, many of which must be dated to a later period, it is likely that the author of the Commentary intended to warn readers against this more common kind of reading. Whether the tendency to frame alchemical texts in philosophical and, more particularly, Aristotelian language was more pronounced in later works or not, Aristotelian ideas, at least, did

60 MA 2.11-20.

61 CAAG 71.18-19. 
not appear to have been formative for Zosimus' thought.

\section{Evidence of Aristotelian influence on alchemical transmutation theories}

If we look more precisely at descriptions of transmutation in which Aristotelian concepts were used, evidence points us to the later alchemical tradition. Changes in the alembic, as described by Stephanus in the early seventh century CE, are just as violent as changes occurring on earth when exhalations circulate in sublunary space. Stephanus was referring here to the Meteorologica, in which Aristotle explained how minerals were formed by the burning or condensing of dry and humid exhalations inside the earth. ${ }^{62}$

Aristotelian influence is most clear in the Commentary on the Treatise According to the Practice by Zosimus attributed to Olympiodorus, where the same exhalation theory can be found:

Similarly [sc. to Zosimus who exhorted to seek refuge in the one god], Chymes following Parmenides says: 'One is the universe and through it, the universe is. If it did not hold the universe, the universe would be nothing.' And the theologians spoke about the divine, the physicians spoke about matter and Agathodaimon, considering Anaximenes, spoke about the air.

And Anaximander spoke about the intermediary, that is to say, about the smoke or the vapour. For Agathodaimon (said) 'certainly it is the sublimate,' as Zosimus says. ${ }^{63}$

The gloss to Anaximander's "intermediary," "the smoke (kapnon) or the vapour (atmon)," is an allusion to the dry and humid exhalations of Aristotle's Meteorologica, where they were said to be "smoky" (kapnoeidess) and "full of vapour" (atmidōdēs). From the fragments of Anaximander's works that remain, we could say at best that he conceived of the principle of all things, the "unlimited," as an intermediary between air and fire or between air and water. ${ }^{64}$ However, it would seem self-contradictory that he thought that this intermediary would have been one of the four elements. The quoted passage attempts to insert different authorities into the context of Aristotelian physics and, from the preceding discussion, we can then reasonably expect

62 9.245.3 Ideler. See Viano, “Aristote et l'alchimie grecque,” 197.

63 CAAG 84.12-18.

64 See A16 DK. 
that the text from Zosimus (just like those of the Presocratics and also probably of Agathodaimon) did not refer to Aristotelian theories.

The Summaries for Eusebeia, attributed to Zosimus, quote a sayings attributed to Aristotle - absent from his extent works - according to which qualities mix with one another but that bodies do not. ${ }^{65}$ The fact that the Summaries to Eusebeia quoted Stephanus (who wrote after Zosimus) casts doubt on the attribution of all sub-treatises of this work to Zosimus. But even if we were to agree that, on the contrary, all sub-treatises of the Summaries should be attributed to Zosimus, this quote do not show that Zosimus consistently thought along Peripatetic lines, since we have no indication that Zosimus subscribed to a single school of philosophy.

It is not surprising that alchemical texts, including those that can be securely attributed to Zosimus, show that he used the Aristotelian notions of potentiality and actuality. But as will be shown below, this Aristotelian influence did not inform what Zosimus had to say about transmutation. Before interpreting this passage it will be useful to look at two other theories he never explicitly held: the "dye-vehicle" of Synesius to Dioscodorus and the self-transforming ashes or residues of the commentary attributed to Olympiodorus of Alexandria.

\section{Synesius, Olympiodorus and the form-transfer theory}

In alchemical texts, the Greek verb "to turn" (strephō) or "to bring inside out" (ekstrephō) is likely to have meant what we now understand as transmutation, i.e. a complete transformation, as strephein was used in the Septuagint to describe how the staff of Aaron had been "turned" into a snake (strapheisan eis opsin). ${ }^{66}$ Like "gold-making" (chrusopoiia), however, the meaning of

65 The same attribution can be found in the fragments of Arius Didymus (in Hermann Diels, Doxographi Graeci [Berlin: Walter De Gruyter, 1965], 449,). Galen (late second century CE) also both associated this idea with the Peripatetics. See Galen, In Hippocratis de natura hominis in Karl G. Kühn and Friedrich W. Assmann, Claudii Galeni Opera Omnia (Leipzig: C. Cnobloch, 1821-1833), 15.32 and J. Von Arnim (ed.), Stoicorum veterum fragmenta, 3 vols. (Leipzig: Teubner, 1903-1905), 2.463. It is probable that this alleged quote from Aristotle was created in the context of the controversy over the Stoic notion of complete fusion, as seen in the De mixtione of Alexander of Aphrodisias (c. 200 CE). Whether this was genuinely Aristotelian or not, by the third century CE, Plotinus (Enneads, 2.7.1.27-29) still considered the controversy relevant and agreed with the Peripatetic position, arguing that the reason qualities could mix without cutting out bodies was that qualities were incorporeal. 66 Exodus, 4.17. 
these two verbs is not devoid of ambiguities since they also refer to the "bringing out" of hidden substances, and thus could have referred to extraction or "reversion" as well.

In Synesius to Dioscorus and in the commentary attributed to Olympiodorus, the verb occurs in a citation of pseudo-Democritus in discussions on the production of "divine water." The quotation found in the Commentary appears as a description rather than an explanation of the "yellowing":

[the entire art depends on the elements]; for after the completion of the iosis and that the projection was made, the stable yellowing will occur. Doing this, bring what was hidden out in the open, for he [Democritus] said, "bring out the nature and you will find what is sought. ${ }^{67}$

Similarly, the text of Synesius to Dioscorus shows that "to transform" ([ek]strephō) was more or less synonymous with "bringing out what is hidden": “- O Synesius, what transformation [lit. turning inside out] is he speaking about? - He speaks about the transformation of the bodies. And how can I turn it [i.e. the nature] inside out? How can I lead the nature outside?" 68 While we commonly understand transformation as meaning a change into something new, alchemical writers appear to have understood by the ekstrophē a return to something that was already present.

Whether "yellowing" and to "bring out the nature" were expressions describing transmutation or superficial (although stable) colouring, these passages offer no explicit theory, in the sense of an explanation, of either processes.

The same can be said of a gloss on the verb (ek-) strephō and cognates found in "On the body of magnesia and its treatment," part of the Summaries to Eusebeia. ${ }^{69}$ The explanation of the

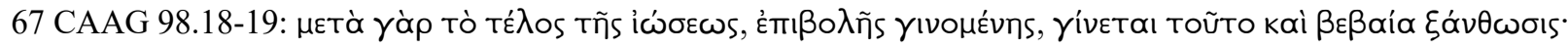

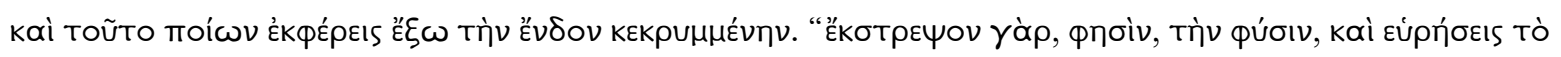

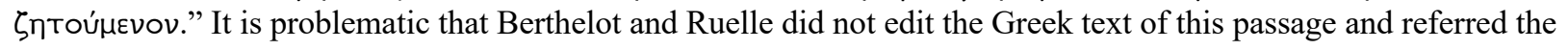
readers to CAAG 223.17-26 instead, an anonymous treatise entitled "On the diversity of burnt copper" (Пєрі

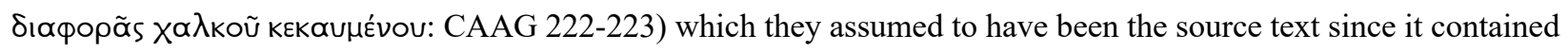
almost the same passage but without the references to other alchemical authors found in the text of the Commentary. In their translation of the unedited Greek text, the passage is introduced by "Tout l'art repose sur les éléments." 68 Syn. Alch. $§ 7$.

69 The attribution of this sub-treatise to Zosimus is complicated by the citation of an unnamed author addressing 
verbs strepsai and ekstrepsai found there is neither clear nor does it seem to have been influenced by philosophy: "So for them, 'to turn/transmute' (strepsai) and 'to turn inside out/transmute' (ekstrepsai) serves the purpose of giving a body to the non-bodies, that is to say, to the 'fleeing' substances." ${ }^{70}$ According to the treatise On Resisting Substances (hupostata) and the Four Bodies, to "give a body to the non-bodies" meant to make substances fire-resistant (see below). This appears to have meant a transformation of some kind, but the context is primarily technical and not explicitly related to a theory of transmutation.

It has been argued, however, that other passages from the alchemical commentary attributed to Olympiodorus and from Synesius to Dioscorus involved a theory of transmutation of the "form-transfer" type implying the creation of prime matter. ${ }^{71}$ Lead was described in alchemical texts as the most basic of metals and could have consequently been considered as a receptive body. A treatise from the Summaries to Eusebeia entitled On the question 'What are substances (ousiai) and non-substances (anousia) according to the Art?' touches on the question of lead as prime matter but does not give any explicit theory of transmutation. It quotes pseudoDemocritus, who said that copper, iron, tin and lead were specifically said to be "substances" (ousiai), and that they were collectively called "the four bodies" (ta tessara sōmata). The treatise also points out that the Egyptians "believed that all 'substances' [ousiai] were made of lead since the three other bodies come from lead." 72 The treatise, however, does not discuss lead's status as primary metal any further. It concentrates instead on techniques to give non-substances the ability to withstand (huphistasthai) fire.

The treatise On the Resisting Substances (ta hupostata) and the Four Bodies according to the sayings of Democritus, also from the Summaries to Eusebeia attributed to Zosimus, discusses the four bodies and similarly concentrates on operative questions. The meaning of hupostata in the text is not explicitly metaphysical and rather linked to dyeing. The word is opposed to "insubstantial" things (anupostata), which are things that "flee" (pheugein), that is to say, to

himself to a woman, a characteristic feature of Zosimus' writings, which sometimes simply address Theosebia with the same "o gunai" ("dear woman") found in "On the body of magnesia and its treatment" (CAAG 194.11-13). 70 CAAG 195.18-21. See also CAAG 196.10-13.

71 Viano, “Aristote et l'alchimie grecque," 199-200.

72 CAAG 167.20-168.5. 
"non-substances" (anousia) that evaporate when heated. 73 "Resisting substances" (hupostata) thus probably refers to the "substances" (ousia) mentioned by pseudo-Democritus, as opposed to the "non-substances" (anousia), which can acquire the capacity to withstand (huphistasthai) fire and thereby become "substances." That this precise meaning was intended, and not that of "substances that serve as support" (as in the translation of Berthelot and Ruelle), is made clear by the fact that the treatise concentrated on the deleterious effect of fire on bodies and on different heating techniques. ${ }^{74}$ The hupostata, then, does not mean "receptive bodies" as far as pseudoDemocritus was concerned, and they cannot stand as the prime matter of the modern formtransfer theory.

To find the closest description of the form-transfer theory of transmutation, we need to turn to Olympiodorus and Synesius' alchemical commentaries. The first important passage is in Synesius to Dioscorus on the Book of Democritus:

Synesius: You did understand, Dioscorus, for as wax takes any colour it receives, in the same way mercury does also, O philosopher; it whitens all substances, draws to itself and absorbs their souls. Since it is processed with the appropriate tools and holds in itself all the moistures and produces corruption, ${ }^{75}$ it takes in exchange all the colours and becomes their support [hupotsatike ginetai], because they are unsubstantial [anupostatōn]. Rather, exactly when mercury becomes unsubstantial [anupostatou autēs huparchousēs], then it may be retained [by the metallic bodies] by means of the treatments carried out using their bodies and their materials.

Dioscorus: And what are these bodies and their materials?

Synesius: They are the tetrasomia [lit. the four bodies] and their related

\section{CAAG 148.8-9.}

74 Ekphsuan in this context probably means burning with an intense heat fanned with bellows. The equipment used must have been called a quontrípıov, as discussed in the quotation from Olympiodorus below (CAAG 91).

75 It is unclear what "corruption" (sêpsis) exactly referred to but it seems that it should be differentiated from "maceration" (taricheia). See P.Holm §29, 103 and140 Halleux, where taricheuo and cognates are related to the preparation of substances before dyeing. On the other hand, oñษ।s seems have been more or less identified with iōsis and to occurred more specifically when the maceration of metals and their "corruption" was meant and the production of a green colour was involved (e.g. CAAG 23.1, 282.7, MA 9.52-62). The sēpsis and taricheia are clearly distinguished in the anonymous Aerial Water (CAAG 210.8-12). See however Syn. Alch. \$19.310-321, where both terms are difficult to distinguish. 
substances. $^{76}$

As the metaphor of the wax indicates, mercury here plays the role of a vehicle for colours. On a theoretical level, this vehicle functions as "that which supports" (hupostatike) and the colour as that which "is unsubstantial" (anupostatos), or, in keeping with the translation of the first term, "that which is not (yet) supported." The implicit theory laid out here involves two abstract terms, "that which supports" (here mercury), and "that which is supported" (the colour considered absolutely, without consideration for its physical support). As Synesius indicated, mercury was conceived both as a support and as a colour. This can be explained by the fact that in order to colour, mercury also needed to function as "that which is supported," becoming both "that which supports [the colour]" in the first iteration and "that which is supported [by the coloured metal]" in the second. It is only by passing through both of these stages that mercury could function as a vehicle for the colours and be "that which supports" as well as "insubstantial," i.e. as that which be supported..$^{77}$ There are then, according to this passage, two theoretical states for substances involved in dyeing: 1) "that which supports," i.e. the "vehicle" for the dyes (or "hypostatic body"), and 2) "that which is insubstantial," i.e. the "colour." Practically, however, there appear to be three different substances considered: 1) the dye, 2) the vehicle for the dye (which also functions as a dye when supporting a colour), and 3) the dyed material, the "bodies and their materials," also called "the tetrasomia and their related substances," and which can be roughly identified as the metals receiving the colours through the action of the vehicle. ${ }^{78}$

The "materials" (hulai) of the four (metallic) bodies, we also learn in Synesius to Dioscorus, are the souls of these bodies, which are also compared to "form" (eidos) ${ }^{79}$ Like carpenters and sculptors who "give form" to bodies of wood or stone, mercury is said to bind form to metallic bodies: "that is how the mercury that we produce with art takes any form and remains - as I said - fixed and strictly bound together with the tetrastoichos [i.e the alloy formed

76 I have followed the text and translation (with slight modifications) of Syn. Alch. $§ 9.136-\$ 10.147$.

77 See the comments of Martelli in Syn. Alch. $\$ 9.144$, n.17.

78 Syn. Alch. $§ 10,1.147$ and 161-162. The expressions "fourfold body" (tretrasomia) and the "body made of four elements" (tetrastoichon sōma) mean the four primary metals, copper, iron, tin and lead—also called the "four bodies" (tessara sōmata; CAAG 167.20-186.1) — and can also mean the stuff from which these metals are constituted (CAAG 235.5-6).

79 Syn. Alch. $§ 10$. 
by the four elements (metals)], which it masters and by which it is mastered." 80 While it is strange-especially from an Aristotelian or Platonic point of view - that the "form" of bodies be called "materials," the text is clear: mercury serves as a vehicle for the colour and also colours bodies, by fixing itself onto the desired surface together with the colour it previously incorporated.

Synesius to Dioscorus mentions that the mercury is bound to the "body of four elements" and that each masters the other. There is only superficial similarity between Aristotle's concept of mixing (mixis), which also involves the same reciprocal relationship, and the relation between mercury and the dyed body. In Aristotelian physics, mixing produces homomerous bodies, by which Aristotle meant uniform compounds such as biological tissues and minerals, themselves forming compounds of homoeomeres, such as the hand. This mixing, Aristotle argued, is the result of the equilibrium between the "dominating" power of two bodies. ${ }^{81}$ As in the fourth book of the Meterologica, the metaphor of reciprocal domination comes to explain processes of specific change, distinguishing mixing from increase (auxēsis). Increase is the domination and assimilation of one form by another, whereas mixing is the transformation of each of the ingredients into that which dominates. Mixing creates a new entity, a compound that is neither one of the two mixed ingredients but "something common and in-between." 82

This is not what Synesius described. There cannot be any Aristotelian mixing since there is no new substance created: as the carpenter fixes a form on a material or a colour is infused into wax, mercury fixes a dye (a form) onto a metal (the body), and "remains fixed ... and strictly bound" with the receptive metallic body. The fact that the bonding of mercury with the dyed metal is expressed as reciprocal domination nonetheless recalls Aristotelian language. Even though it appears that the author of Synesius to Dioscorus here hinted at Aristotelian discussions of change, this was not an attempt to explain processes in terms of Aristotelian physics. Likewise, the language of form and matter and of soul and body is present but simply illustrative. Ancient gilding techniques can more easily account for the explanation given by Synesius (see below).

80 Syn. Alch. $\S 10.160-163$.

81 On the Aristotelian concept of mixing, see n.42. A similar saying is ascribed to Democritus in the treatise on substances and non-substances (CAAG 168.16-19: "Nature, working on what is proper to itself as if it were contrary to itself, becomes strong and steadfast, dominating and being dominated").

82 On Generation and Corruption, 328a23-31. 
The identification of the soul of metals with the "materials" constituting them would also be puzzling in a philosophical context and especially in a Platonic one. We could assume that a writer influenced by Greek philosophy might have opposed "materials" (hulai) to form, perhaps, but not to "matter" (hulē). While this opposition can be explained by reference to other alchemical works, it is not compatible with Aristotelian physics. ${ }^{83}$ Similarly, since mercury "remains ... fixed and strongly bounded" with the metallic body, it does not play the role of prime matter, which would have been entirely transformed into something else. Mercury is rather described as the wax used as a binder for pigments in encaustic painting. Mercury was used to mediate and bind "souls/forms/materials" together, thus enabling the artisan to apply it to the "four bodies" (considered either as an alloy of lead, tin, copper and iron, or perhaps any of these considered individually). In other words, Synesius saw mercury as a medium, gluing a colour "form" to a metallic host "body."

This description is entirely compatible with current and past artisanal refining and gilding techniques. Gold is still extracted in Indonesia and other parts of the world by pulverising auriferous ore, decanting it and mixing the resulting silt with mercury ${ }^{84}$ Mercury amalgamates with most metals and forms a solid metallic lump from the pulverised metal contained in the silt. This metallic amalgam is then fired until the mercury evaporates, leaving an alloy composed of amalgamated particles of metal. The first pages of the alchemical commentary attributed to Olympiodorus allude to the first part of this process, and Pliny and Vitruvius also demonstrate some knowledge of the technique. ${ }^{85}$ The third-century Leiden papyrus - the oldest manuscript of Greek alchemical recipes - also describes how to gild metallic surfaces with mercury, and Pliny confirms that this technique was fairly common knowledge. ${ }^{86}$ One gilding technique, commonly

83 See the explanation in n.15 to Syn. Alch. $\$ 9.127$, where Martelli argued on the basis of the Syriac alchemical manuscript from Cambridge (and in which Pebichius is credited with the saying "all the bodies are mercury") that the "materials" (hulai) could be considered as "souls" because it was thought that a kind of "soul" (or volatile substance, i.e. "mercury") could be extracted from all bodies.

84 See the Blacksmith Institute's Mercury: The Burning Issue on their efforts to contain mercury emission from artisanal gold-refining in Kalimantan: http://youtu.be/FIbhwaw5PQg (part 1) and http://youtu.be/pPGPbbHY03M (part 2).

85 Pliny, Natural History, 33.32 (99); Vitruvius, On Architecture, 7.8.4.

86 Natural History, 33.32 (100). See P. Leid. 1.321-331 Halleux with the useful technical notes from Halleux in Papyrus de Leyde, Papyrus de Stockholm, 98, n.1.Vitruvius also mentions this technique in passing (On 
known as fire-gilding and apparently ignored by ancient and late antique sources, ${ }^{87}$ consisted of creating a metallic paint by dissolving the desired coating metal in mercury to form a liquid amalgam, then covering an object with it and slowly heating that object. Since mercury has a very low ebullition point, the mercury in the amalgam quickly volatilises and a thin layer of the coating metal stays glued to the object's surface. Another technique, called "cold gilding," probably described here by Synesius as well as by Pliny, consists of gluing thin sheets of gold over the surface of a metal that has been previously heated and covered with mercury:

The copper is first subjected to the violence of fire; then, when it is red hot, it is quenched with a mixture of brine, vinegar, and alum, and afterwards put to a test, its brilliance of colour showing whether it has been sufficiently heated; then it is again dried in the fire, so that, after a thorough polishing with a mixture of pumice and alum, it is able to take the gold-leaf laid on with quicksilver. ${ }^{88}$

Mercury functions in both techniques as a vehicle for gold or precious metals, which is also probably what Synesius had in mind. Mercury, for Synesius, was not the hypothetical prime matter attributed to Aristotle. Rather, it was a vehicle for pigments.

Olympiodorus commented on the passage from Synesius quoted above and formulated a different statement, which appears as a genuine transmutation theory:

What else can be said [about the citation of Synesius]? That when mercury is 'loved by the art' [philotechnoumenē] it becomes 'that which supports' [hupostatikē] and that, being insubstantial [anupostatou], it changes along [summetaballomenē] with any liquefied body? Once it has lost its constitution, it becomes volatile [pheuktē]. In a similar fashion, our magnesia, antimony, pyrites, and minerals — or what we call bodies that are drawn down ${ }^{89}$ with oil and

Architecture, 7.8.4.).

87 See Ottavio Vittori, "Pliny the Elder on Gilding: A New Interpretation of His Comments," Gold Bulletin 12 (1979): 35-39. I would like to thank an anonymous Ambix reader for this reference.

88 Pliny the Elder, Natural History, 33.20, trans. Rackham (Cambridge, MA.: Heineman, 1952).

89 The meaning of kataspao in this context is not entirely clear. The literal meaning is "to draw down" and it is in this sense that Mertens translated it (MA 7.37 = CAAG 238.20). It appears to have been used to describe the separation of the slag (skôria) from the ore. The slag would liquefy and flow down the furnace. See Robert J. Forbes, Studies in Ancient Technology, vol.8 (Leiden: Brill, 1971), 35-39, and Aristotle, Meteorologica 4.383a32-b2 with Lee's comments in the Loeb edition (Cambridge, MA: Heinneman, 1951) and Pierre Thillet (Paris: Gallimard, 2008). 
soda, ${ }^{90}$ with an automatareion, ${ }^{91}$ or a phusèterion (whatever one wants to call it), ${ }^{92}$ - are drawn down to (their) constitution and are turned into ashes. And the fixating body/the body suitable for instantiation, which they call 'black lead,' and which the Egyptian prophets desired to know and which the oracles of the demons delivered, are the ashes and the residues ${ }^{93}$ of Maria. For they have known that these have existed from the beginning. Blackening happens because of this. During the practice, un-blackening, that is to say, whitening (happens because of this). For nothing else signifies whitening if not the discolouration by privation of the black.

And see the concision, wise one. For you possess the entire work of the captive. You possess what has been sought for ages. I know that you have long endured the pain of wisdom. This is the key of the discourse, and it is the summary of the entire art. Do not overlook what is inside for it opens for you the doors of the contemplative and of the practical, knowing that the residues are the entire hidden doctrine. For all look for these and are hanging onto them. Countless allegories refer back to then and just as many books allegorise them. For they explain whitening and yellowing.

For there are two colours that are diametrically opposed, white and black. White distinguishes but black comprehends. Zosimus allegorised this when he said: 'it surrounds the pupil of the eye and the heavenly iris.' Those who are ignorant do not realise what distinguishes and what comprehends. What comprehends and

The verb is used generally to describe the production of a black material (CAAG 88.21,130.3, 155.11, 195.19, 197.19, 203.3, 223.6-7), sometimes referred to as skōria, skōridia (slag, residues) or melas molubdos (black lead). It might also have referred to operations in the alembic rather than the smelting furnace, in which case it might also have meant the deposition of a vaporised substance into a solid. It is unlikely that it meant a precipitation (the formation of a solid inside a liquid) as stated in the LSJ.

90 Nitrelaion. Such a mixture would produce a detergent. If kataspaō is used here as part of smelting, this might have served as a flux, a product facilitating the separation of the gangue (undesired material in the ore) from the bloom (the unrefined, desired metal). See Forbes, Studies, 36.

91 Instead of automatareiōi, A and L have autōi tōi botaiōi. Elsewhere, the bōtarion appears to be the bottom part of a still (see CAAG 60 with MA cxxi).

92 Most probably an apparatus with bellows (phusètēr, phusai). The opposition here would be between the slow cooking of the automatareion (a hapax, which Berthelot and Ruelle translated as "digesteur") and the fast cooking of an instrument with bellows.

93 Skōridia, "dross." Literally, "little slag." 
what is much compacted is extracted ${ }^{94}$ from the appropriate body. The nature of lead that is drawn down is extracted from the liquid substance, as the divine Zosimus says ${ }^{95}$ — he holds fast to the whole truth of the knowledge of god. No longer revealing the invisible cosmos in itself, the soul reveals (itself) differently in another body of silver, and in silver, the fiery blood, that is to say, gold. ${ }^{96}$

The passage can be divided into three parts. The first is a commentary and expansion on the text of Synesius seen above. The second is an appeal to past authorities and the third appears to be an ambiguous theory of transmutation.

The passage first recapitulates what Synesius wrote about mercury: mercury is "that which supports" (hupostatikē) when it is itself "insubstantial" (anupostatos), while "that which supports" also changes along with liquefied bodies (summetaballomenē). Most importantly, the passage develops the concept of the supportive body by introducing the notion of "residues" (skōria/skōridia), which are described in the middle section as crucial for whitening and yellowing (i.e. silver and gold dyes). These residues are obtained by "drawing down” (kataspāo) minerals, which are said to gain properties analogous to mercury in the process. This, the text states, is what the oracles of the Egyptian prophets called "black lead," and this black lead is what Synesius to Dioscorus called "that which supports" (hupostatikē).

We could then expect that the author of the commentary thought that the residues functioned as a vehicle for dyes, following Synesius to Dioscorus, but the third part of the passage seems to lead to another conclusion. By saying that the "soul" extracted from the residues "no longer revealing in itself the unseen cosmos ... reveals itself differently in another body of silver," 97 we could be led to believe that the "soul," i.e. the pigment, when mixed with substances, transforms them into silver. By describing the alchemical process of whitening as the removal of black, we are led to think analogically that the colour represents the residues, which are called the "black lead." This "soul," like the colour black, would "be comprehensive"

94 Katakomizo + hupo is a hapax in the alchemical corpus. Its meaning might be the same as kataspaō. Ruelle and Berthelot translate it as "to extract" or "to pull out from." The notion that lead is extracted from the liquid substance is supported by the fact that the liquid substance is said to contain lead later in the treatise (CAAG 93.4-5).

95 Perhaps referring to CAAG 197.19-198.7

96 CAAG 91.5-92.15.

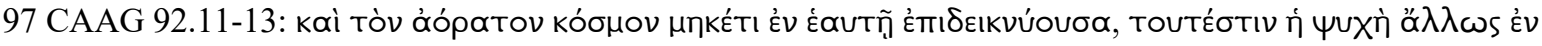

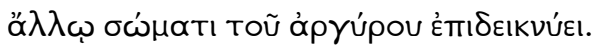


(sunektikos) of the form of silver and gold, and would be able to produce them. Later in the commentary, Olympiodorus states that the "liquid essence" or "soul" "sinks and attracts all things into itself," which could mean that it contains all forms ${ }^{98}$ since in L, one of the manuscripts used by Berthelot and Ruelle, the colour black is also described as "the source of all other colours." 99 The reading of this manuscript reinforces the notion that this "liquid essence," "black lead" or "residue" would have included all forms/souls in itself just as the colour black would include all colours. The fact that the soul is said to have stopped revealing the "cosmos" in itself to reveal silver and gold in other bodies also suggests that the soul was "comprehensive" of all forms to begin with.

If by sunektikos Olympiodorus meant "comprehensive of forms," his text is a good example of an ancient transmutation theory similar to the form-transfer theory. This interpretation is supported by a parallel in the recipe entitled On the Same Divine Water, in which the residues (skôria) of distilled eggs - the egg being a metaphor for the cosmos ${ }^{100}$ —are the only ingredients used to produce a powder that transforms silver into gold. ${ }^{101}$

Neither Synesius nor Olympiodorus considered mercury or the "residues" to be formless matter. Furthermore, the processes they discussed were not aimed at producing an unqualified substrate but at producing something that could impart colours, qualities or qualitative changes to other substances. Even if they used philosophical vocabulary, Synesius and Olympiodorus did not derive their procedures from Greek philosophy, and nor did they attempt to explain their practice from the point of view of a single philosophical system. As I will show in conclusion, Zosimus was even less interested in explaining dyeing processes in terms of philosophical systems. In fact, his theorisation of dyeing processes took him beyond the realm of physics.

\section{Zosimus and alchemical theorisation}

98 CAAG 93.7-9.

99 See the apparatus criticus to CAAG 93.1

100 See the "Glossary of the Egg," CAAG 20.18-19.

101 MA 9. On sound philological grounds, Michèle Mertens no longer believes that this text should be attributed to Zosimus (e-mail message to author, 7 June 2013). My forthcoming “Transmutation Theory and the Dating of On the Same Divine Water" in Epekeina substantiates this claim. 
As I have noted before, the attribution of the Summaries to Eusebeia is not a settled question and, for the sake of the argument, I have decided provisionally not to attribute this group of texts to Zosimus. All things considered, it would still be possible that Zosimus used the term hupostatikos to mean "that which supports" in the section of the Summaries to Eusebeia seen above. ${ }^{102}$ While calling these substances "resisting" (hupostaton) did not mean that they were "receptive bodies," the text also states that copper and silver can be "that which supports" in the sense given to the word in Synesius to Dioscorus and in the commentary attributed to Olympiodorus. This might imply some similar dyeing theory:

For nowhere in the writings is something that is resisting [hupostaton] mentioned, if only for copper, (about) which Maria says that copper is treated and afterward burnt and that it will become supportive [hupostatikos]. Thus is the copper or the silver in our enterprise. And we do not want to take the qualities [poiotēta] out of them, for their dead body is useless and plants are useless too. Indeed, they are usually destroyed by fire. ${ }^{103}$

While hupostatikos does appear here to have had the same meaning as in Synesius to Dioscorus, "that which is supportive" could not have been considered to be prime matter since it is expressly stated that must not be emptied of its qualities. Consequently, "that which supports" could not play the role of the unqualified substrate in a form-transfer theory of transmutation. The treatise rather seems to describe what the commentary attributed to Olympiodorus meant when it discussed the creation of "that which supports" by burning the substances into "ashes and residues" (a process it called "to draw down") and recalls the preparation of the gilded surface as described by Pliny.

Viano argues that the notion of prime matter is implied in two other passages of the First Lesson on Excellence attributed to Zosimus. ${ }^{104}$ In the first passage, Zosimus interprets the axiom according to which "the nature wins over the natures" by describing how nature takes back "the common appearance of the universe" and devours "the particular matter of the species" during

102 CAAG 148-153: “On the Resisting Substances (ta hupostata) and the Four Bodies according to the sayings of Democritus."

103 CAAG 151.15-20.

104 Viano, “Aristote et l'alchimie grecque,” 199-200. 
the work (ergasia). ${ }^{105}$ In the second, Zosimus says to transform nature "as if it was made of only one material." 106 In both passages, Zosimus likens the "work" to the workings of nature, considered as single and uniform. In the first passage, a part of the pseudo-Democritean axiom is interpreted to mean the process by which nature sheds its outward appearance and material diversity to reveal its common appearance (i.e. its "monospecificity," the idea that "the All is one"). The second passage shows more clearly that, for Zosimus, alchemical inquiry is a network of ideas and practices comparable to the works of nature. Zosimus uses allegory to illustrate the paradox of a "monospecific" (i.e. including only one species) but "all-variegated" Nature (discussed further below). The point of his dream-interpretation and allegorical discourse, I believe, is not to identify a specific substance or state of matter with an alchemical prime matter, but to draw a comparison between the goal of the "work," gold, and the "goal" of nature, unity. To clarify this point, I must now turn to Zosimus' First Lesson on Excellence.

\section{Cyclical processes in Zosimus' Lessons on Excellence}

Zosimus' objective in this treatise is to describe transformations in nature as multiple but also as one self-reflexive process in which "all things are combined and all things are separated." 107 The First Lesson on Excellence is composed of two dream narrations and concludes with an interpretation of these dreams, including a recipe meant to produce "the monospecific out of multiple species," also designated as "that which is called gold."108 The substantive "monospecific" (to monoeidon), as applied both to the world and to gold, recalls the use made by Plato of the adjective "simple" or "unique" (monoeidess) to describe gold (Timaeus 59b) and being (Phaedo, 78d). Plato opposed the "simple," which he associated with the soul, the divine, the indestructible, and what is always equal to itself (i.e. "the same"), to the body, which he associated with that which is human, mortal, non-intelligible, multi-shaped, destructible and what is never similar to itself (i.e. "the other"; Phaedo, 80b). Zosimus must have referenced both gold and being in his description of nature as a whole, conflating two ideas and two different fields of

105 MA 10.6.124-128.

106 MA 10.7.133-135.

107 MA 10.4.85-86.

108 MA 10.8.148. 
inquiry: 1) gold refining, gilding and what is called more generally "yellowing," which relates to the technical aspect of alchemy; 2) the paradox of nature's fundamental unity, which relates to Greek physics. These are the very first lines of the treatise, which introduce the dreams and show the universal scope of the work (MA 10.1-16):

Rest of the waters, movement, increase, disembodiment, embodiment, extraction of pneuma from a body, tying of pneuma to a body, these are not (coming) from natures that are foreign or brought from outside; rather, the monospecific [monoeidess] nature possesses the hard shells of the minerals as well as the humid pulp of the plants itself and only with respect to itself. ${ }^{109}$

And the inquiry and the great complexity of the universe, which is diversely materialised, takes shape in this multicoloured, monospecific species [monoeidei]; for this reason nature lays down [hupoballei; perhaps 'injects'] the cessation and the increase by which it hides [hupopheugei; perhaps 'flees'] as it is chronically 'moonstruck' [i.e. as the moon cyclically waxes and wanes]. ${ }^{110}$

That this should be seen as a programmatic statement of the following dream might be deduced from the fact that Zosimus says he fell asleep after saying these lines, and that he interprets the first dream as the "rest of the waters," the first words of this preamble. The following dream narration begins with a silent sacrificer (hierourgos) standing in front of a bowl-shaped altar $^{111}$ at the top of a staircase (17-28). Zosimus writes that a voice came from inside the bowl-altar, saying (28-36):

I am Ion, the priest [hiereus] of the temple's shrines and I undergo an intolerable violence. At sunrise, someone came running and mastered me, dividing me with a knife, pulling me apart according to the structure of my constitution and skinning my head with the sword he held. He combined [suneplexen] the bones with the flesh and he burned (them) with the fire in his hand until I learned to become pneuma by changing my body. This is the intolerable violence I endure.

Pressed with more questions, the priest underwent a series of torture-like experiences. His eyes

109 MA 10.1-6.

110 MA 10.7a-16a. Note that Mertens has published two different versions of this passage. I have here retained only one.

111 Phialobōmos and bōmos phialoeidēs. The bowl-altar is likened to an apparatus by the use of the term philē, a libation vessel, but also a common term for the top part of the alembic. 
became like blood and he "vomited all his flesh." Transformed into a "small mutilated human" (anthroparion kolobon), he then proceeded to chew himself up until he finally "fell upon himself" (sumpiptonta) (36-41). After this gruesome vision-reminiscent of the literal meaning of an ekstrophē (an "inversion," but also followed by a "reversion")—Zosimus awoke and interpreted the dream as the "rest of the water" (41-42).

In the second dream (44-73), Zosimus approaches another bowl-shaped altar which contains many people, boiling and screaming. Questioning a "small, dry-making human"112 on "the boiling of water and humans burning up yet living," the creature describes these activities as the "entrance, exit and transformation." Intrigued, Zosimus requests more information about the "transformation," and the "small human" replies: "The place of the exercise is called 'maceration/embalming' [taricheia] because humans wishing to reach excellence enter here and become pneuma after escaping the body" (54-57). After another episode that should not distract us here (59-69), a character called the "master of the house" (oikodespotēs) tells Zosimus:

the one whom you have seen as a copper-human and who vomited his own flesh [i.e. Ion the priest] is the sacrificer [hierourgōn] as well as the one who is sacrificed [hierourgoumenos]. He is also the one to whom was given dominion over the water and over those who are chastised. (70-73)

Awakening from the second vision, Zosimus launches into a description of nature, revealing the circularity of natural processes by adding opposite pairs of active and passive elements: "The mineral gives and the plant takes. The stars give and the flowers take. The sky gives and the earth takes, etc." (77-90). Moving from specific exchange processes to higher levels of abstraction, Zosimus claims that the universe undergoes cycles of combination and separation: "Everything is intertwined (sumplekontai ta panta) and everything is separated (apoplekontai). Everything is confused and everything is organised. Everything is combined and everything is separated" (85-

112 I follow the reading of M, xērourgon anthrōparion. A and L instead have "razor-wielding" "little men/puppet" (xurourgon anthrōparion) here and in the Second Lesson (MA 11, not found in M). Building on the same (or similar) physical notions that made Heraclitus compare a beam of light to a "dry soul, excellent and very wise" (DK 118), and who described the witless soul of the drunkard as "humid," Galen also considered intelligence to be blunted by humidity and sharpened by dryness (Quod animi mores corporis temperamenta sequantur, 4.780-782 and 4.786.8-14 Kühn). Since the "homunculus" teaches how to transform the body into pneuma, it would make better sense to follow M here, and call him "dry-making." 
88). "To put it briefly," he writes, "if method is not left behind, all things harmonized through separation and union turns nature inside out/transforms nature" (95-99). ${ }^{113}$ To conclude this first explanation, Zosimus writes that the fact that nature "turns" on itself (ekstrephō), that is, that it "transforms itself," means nothing else than "the order and the connexion of the excellence of the entire cosmos." If we can accept that the title of the treatise was provided by Zosimus himself, this universal connexion, which is a process of transformation, would be the topic of the entire treatise, which Zosimus called nature's aretē, its "excellence" (also "goodness" and "fame").

The same idea is rehearsed in Zosimus' final dream-interpretation, which is itself an allegory mixing many of the symbols seen above (100-113):

In short, my friend, build a monolithic shrine for yourself that is like white lead, like alabaster, like (marble) of Proconnesus, and which has neither beginning nor end in its construction. Inside, it has a source of the most pure water and a light shining like the sun. Seek diligently for the entrance of the shrine, take a sword in your hand and thus search for the entrance. For the place where is the opening is narrow-mouthed and there is a snake lying next to the entrance, guarding the shrine. Once you have mastered it, first sacrifice it and having skinned it and taken its flesh and its bones, divide (dieleisi) it part by part. After you have recomposed (suntheis) its parts one by one with the bones, make yourself a base next to the entrance of the shrine. Climb, enter and you will find there what is sought for.

The snake in alchemical texts is often depicted as an ouroboros, the tail-biting snake. It is an obvious symbol of circularity, and is also sometimes taken to represent alchemical processes. ${ }^{114}$ The snake is identified with alchemy, and doubly so here due to the circularity of the complete sacrifice of the snake. It needs first to be entirely dismembered, its flesh separated from the bones, and its body systematically recomposed afterwards. This separation and recomposition of the snake's corpse is meant to complete the alchemical process, and the circularity of the process is made clear by the homologies between the sacrifice of the "snake" and of Ion. Ion explained that he was divided with a knife "according to the structure of his constitution" and that his flesh and bones were afterward "woven together." Similarly, the snake

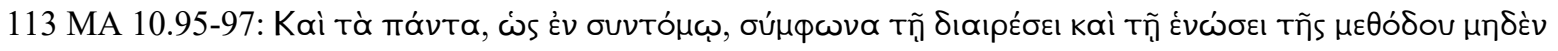

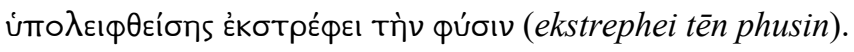

114 See CAAG 21.20-23.7. 
must also be flayed, its flesh and bone separated, and then reassembled. Moreover, when describing the excellence of the cosmos, Zosimus uses the exact same textile metaphor seen in the case of the weaving (sumplokē) of Ion's flesh and bone: nature methodically weaves and unweaves things, that is to say, it separates and unifies the things it comprises, thus transmuting itself and ensuring its "excellence" in the process (91-99).

However we want to consider these allegories, this analysis shows that Zosimus compared ekstrophe to circular processes of combination and separation such as those he saw occurring in nature, rather than to the adding of qualities to an unqualified substrate. It also shows that, contrary to later authors, Zosimus theorised about alchemical and natural processes using almost no Greek philosophical vocabulary and using no Greek physical concepts. Rather, he wrote allegories, and allegories of these allegories.

\section{Conclusion}

The concept of the so-called hypostatic (hupostatikos) body did not function as a sort of prime matter or unqualified substrate in a theory of transmutation inspired by Aristotelian physics. Rather, Synesius to Dioscorus use "that which is receptive" to describe that which receives a colour, in what appears to have been a cold-gilding process as described by Pliny the Elder and Vitruvius. However, the notion of "ashes" or "scoria" in the commentary attributed to Olympiodorus might have underpinned a theory of transmutation similar to that described by some modern commentators, in which the process of blackening brought matter to a state in which the "seminal blueprints" it contained could be re-actualized (and, perhaps, selected) in order to produce gold. The potentiality of the "residues" was not the pure potentiality of matter from an Aristotelian point of view but the potentiality that was "comprehensive"; that is to say, that it already included the "seeds" of everything in itself.

Less speculatively, it can be concluded from the fact that none of the passages studied here considered the blackening as the production of an "Aristotelian" unqualified substrate to which could be added the quality of gold. On the contrary, we can see that different alchemical texts discuss transmutation differently and that they rarely make a clear distinction between dyeing and transmutation. Moreover, Aristotelian philosophy appears to have had more of an impact on alchemical terminology than on alchemical theorization. 
That is not to say that alchemical writers did not think about transformative processes. Zosimus appears to have been more interested in theorizing transmutation. To appreciate his theoretical ideas about physical transformation, however, we must look for allegorical, i.e. analogical writings, rather than for a systematic theory. Reading his allegories as simple codes for the beliefs he held would force a deductive and systematic reading on a form of writing that most evidently avoided the systematisation of what he called "demonstrative reasoning" (logos apodeiktikos) and which he could also used if he wished. Allegorical writing for Zosimus was a careful way of relating different processes without reducing the phenomena to a single and coherent system of explanation. The First Lesson on Excellence expressed a fundamental idea popular among Presocratic monists: the notion that the universe as a whole, and not just metals, can ultimately be reduced to a single thing. This is why Festugière remarked that it was particularly strange that this theory was attributed to Democritus, whose first principles were unlimited in size, number and shape. ${ }^{115}$ This was not simple provocation or ignorance. Zosimus and other alchemical authors simultaneously presented the universe as a composition of elements and as a non-composite thing. By describing nature as "monospecific," Zosimus did not explicitly follow a clear theory equating one metal with the material substrate of all other metals. He was more interested in attempting to conceptualise nature and its variegated species as a single, noncomposite thing.

If Zosimus sometimes felt the need to write allegorically rather than technically, it is probably because he thought that he could not make truth-claims. Making truth-claims is the work of allegorical interpretation, not of allegorical writing. The difference between reading alchemical allegories as codes for technical or philosophical content and reading the same allegories as establishing parallels rather than identities is decisive for understanding how Zosimus discussed dyeing techniques in connection with his anthropological, theological and eschatological ideas, without confusing the technical and the theoretical levels. In other words, Zosimus appears to have considered dyeing techniques as transmutation techniques in as much as they were considered to be analogical to an eventual "reversion" (ekstrophe $)$ of humans to the pre-incarnation, "pneumatic," "interior" and paradigmatic human, which he called Phoss. Philosophical terminology and references to philosophical authorities are not as pervasive in the works attributed to Zosimus as they are in works that quote him, which were most probably

115 Festugière, La révélation, 234, citing CAAG 168.4-5. 
written later (unless we accept the likely possibility that Zosimus was also the target of later pseudepigraphists). Philosophical terminology and references rather appear to have grown in importance in the later commentaries attributed to Synesius and to Olympiodorus, as well as in the work of Stephanus. Combined with other criteria already used, this new criterion could help us secure the dating of these and other texts, especially those which have come down to us in epitomes, like the Summaries to Eusebeia, and which are particularly complicated to date.

\section{Acknowledgements}

This work was made possible through the support of Paul-Hubert Poirier and the generosity of the Fonds Québécois de la Recherche, Sciences et Société and of the Distant Worlds Graduate School at the Ludwig-Maximilans-Universität. I would like to thank Jay Stemmle for her comments and to Tessa J. Brown for her help with proofreading. I would also like to thank an anonymous reader from Ambix and Jennifer Rampling for their comments and help.

\section{Note on contributor}

Olivier Dufault is a postdoctoral fellow at the Distant Worlds Graduate School, part of the Münchner Zentrum für Antike Welten at the Ludwig-Maximilians-Universität. Address: LudwigMaximilians-Universität München, Room V 334, Schellingstr. 3, München. Email:

o.dufault@campus.lmu.de 